\title{
The Height Regularities of the Water Industry Balance of Georgia
}

\author{
Nino Kezevadze \\ Head of ltd "Georgian Water and Power", Tbilisi, Georgia
}

Email address:

nino-kezevadze@rambler.ru

\section{To cite this article:}

Nino Kezevadze. The Height Regularities of the Water Industry Balance of Georgia. Earth Sciences. Special Issue: Modern Problems of Geography and Anthropology. Vol. 4, No. 5-1, 2015, pp. 24-29. doi: 10.11648/j.earth.s.2015040501.15

\begin{abstract}
The current political and socio-economic changes in the last centuries of 90-th was adequately reflected on water management problematic issues. There is a lack of statistical material that complicates the research activity. To this point of view the primary task was to choose representative period in the dynamic of utilizing water recourses. 80-th of last century is considered as such kind of period stated in the previous article. In terms of territorial differentiation water industry balance is estimated in the previous article according to the high-rise zones of western and eastern Georgian regions. The annual quantity of river runoff on the territory does not depict completely the water supply of population and various branches of economy. The full assessment is possible by the intra annual mode of water balance in the hydrological periods and phenological seasons. On the other hand, in Georgia, in mountain regions the elements of water balance are amenable to high-rise regularities, so the intra annual mode of water balance should be considered in the context of high-rise extent. The previous work is devoted to territorial distribution of indicators of water balance in Georgia according to high-rise zones in the frame of intra annual aspect.
\end{abstract}

Keywords: Water Industry Balance, Water Resources, Height Regularities

\section{Introduction}

Assessment of the water industry balance of Georgia as of a mountainous region must be made according to height levels as the water resources, the demographic and industrial characteristics of the territory depend on height variations $[1$, 2].

Quite often, distribution of water resources according to height profile functionally is in regenerative connection with demographic and industrial development. Georgia belongs to the list of such countries. Its mountainous parts, which occupy nearly half of the territory and contain $80 \%$ of the water resources of Georgia, are economically less developed and sparsely populated. On the inter-mountain lowlands where during the reporting period more than $90 \%$ of population lives, $95 \%$ of the industry is located and approximately $90 \%$ of irrigated agricultural lands is met only $20 \%$ of water resources is used. On the inter-mountain lowlands distinguished with developed water industry and high density of population there are no more territories left unused regarding industry. Therefore, here significant deficiency of water resources has been observed, especially in the low-water seasons when the demand on water by the mountainous regions is fully satisfied just by the least portion of the local water resources. Consequently, the specific water supply rate of the population in mountainous regions is noticeably high than of those in the lowlands. In Georgia the least water supply is characteristic of the territory of East Georgia with the high density of population and limited water resources -0.45 thousand $\mathrm{m}^{3} /$ year; the highest rate of water supply is characteristic of the mountainous region of West Georgia - 317 thousand $\mathrm{m}^{3} /$ year.

All the above mentioned circumstances make it necessary to assess and study the water industry balance according to height profile as despite the over-abundance of water resources in the mountainous regions when planning their usage it is very important to preserve such amount of water supply that will provide positive water industry balance in the whole basin (including lowland regions) [3, 4].

\section{General Overview of Height Regularities of the Water Economy Balance of Georgia}

The article considers the water supply balance of the whole territory of Georgia as well as its separate eastern and western parts for 3 height profiles: $<500 \mathrm{~m} ; 500-1000 \mathrm{~m} ;>1000 \mathrm{~m}$ 
(Table 1, 2, 3) $[5,6]$.

Table 1. The Height Regularities of the Water Economy Balance of Georgia.

\begin{tabular}{|c|c|c|c|c|c|c|c|c|}
\hline \# & $\begin{array}{l}\text { Main Water } \\
\text { Consumers }\end{array}$ & $\begin{array}{l}\text { Altitudinal } \\
\text { Belt }\end{array}$ & $\begin{array}{l}\text { Water } \\
\text { taking }\end{array}$ & $\begin{array}{l}\text { Water } \\
\text { Supply }\end{array}$ & $\begin{array}{l}\text { Returned } \\
\text { Water }\end{array}$ & $\begin{array}{l}\text { Non-returned } \\
\text { Waters }\end{array}$ & $\begin{array}{l}\text { Polluted } \\
\text { Waters }\end{array}$ & $\begin{array}{l}\text { Dilution Volume } \\
\text { of waste waters }\end{array}$ \\
\hline & & $<500$ & 623 & 540 & - & 161 & 379 & 6200 \\
\hline \multirow[t]{3}{*}{1} & Urban Population & $500-1000$ & 40 & 35 & - & 10 & 25 & 410 \\
\hline & & $>1000$ & 12 & 10 & - & 4 & 6 & 100 \\
\hline & & $<500$ & 1282 & 1782 & 671 & 294 & 817 & 9390 \\
\hline \multirow[t]{3}{*}{2} & Industry & $500-1000$ & 224 & 312 & 118 & 51 & 143 & 1650 \\
\hline & & $>1000$ & 22 & 30 & 11 & 5 & 14 & 150 \\
\hline & & $<500$ & 1005 & 1058 & 193 & 110 & 755 & 3770 \\
\hline \multirow[t]{3}{*}{2.1} & Hit-energetic & $500-1000$ & - & - & - & - & - & - \\
\hline & & $>1000$ & - & - & - & - & - & - \\
\hline & & $<500$ & 1522 & 841 & - & 648 & 193 & 1050 \\
\hline \multirow[t]{3}{*}{3} & Rural Economy & $500-1000$ & 931 & 513 & - & 395 & 118 & 600 \\
\hline & & $>1000$ & 204 & 123 & - & 99 & 24 & 230 \\
\hline & & $<500$ & 134 & 104 & - & 90 & 14 & 350 \\
\hline \multirow[t]{3}{*}{3.1} & Rural Population & $500-1000$ & 73 & 57 & - & 50 & 7 & 170 \\
\hline & & $>1000$ & 38 & 30 & - & 26 & 4 & 100 \\
\hline & & $<500$ & 52 & 40 & - & 35 & 5 & 180 \\
\hline \multirow[t]{3}{*}{3.2} & Livestock Farming & $500-1000$ & 34 & 26 & - & 23 & 3 & 110 \\
\hline & & $>1000$ & 26 & 20 & - & 18 & 2 & 70 \\
\hline & & $<500$ & 1336 & 697 & - & 523 & 174 & 520 \\
\hline \multirow[t]{5}{*}{3.3} & Irrigated Agriculture & $500-1000$ & 824 & 430 & - & 322 & 108 & 320 \\
\hline & & $>1000$ & 140 & 73 & - & 55 & 18 & 60 \\
\hline & & $<500$ & 3427 & 3163 & 671 & 1103 & 1389 & 16640 \\
\hline & Total & $500-1000$ & 1195 & 860 & 118 & 456 & 286 & 2660 \\
\hline & & $>1000$ & 238 & 163 & 11 & 108 & 44 & 480 \\
\hline
\end{tabular}

It is noteworthy that the reporting period is considered the 80 -ies of the previous century as the historically most active period in the industrial development of the country with relatively reliable water industry statistics, steady social-economic background and maximum industrial use of water resources.

The water industry estimations made it obvious that for the reporting period 6 the water amount necessary for dilution of the public, industrial and manufacture waste waters on the inter-mountain lowland of East Georgia first exceeded the local water resources of the territory and the water amount necessary for dilution of the public, industrial and manufacture waste waters in the up-to-1000-m height zone was equal to the whole resource potential of the river flow of East Georgia.
There is a quite different situation in West Georgia where industrial products, irrigated agricultural lands and a significant amount of the population are located in the 0-500 $\mathrm{m}$ zone. Here the appreciable loss for the population, agriculture and industry is less than $1 \%$ of the full river water flow and $2.4 \%$ of the sustainable water flow, and the waste water dilution requires $12 \%$ of the water resources of West Georgia. Consequently, in the reporting period, unlike East Georgia, the inter-mountain lowland of West Georgia did not confront with the burning issue of the water industry optimization, though there were certain basins with uneasy water industry balance. It means that West Georgia to some extent but in lower degree also needed to adopt more practical measures regarding the water industry.

Table 2. The Height Regularities of the Water Economy Balance of East Georgia.

\begin{tabular}{|c|c|c|c|c|c|c|c|c|}
\hline \# & $\begin{array}{l}\text { Main Water } \\
\text { Consumers }\end{array}$ & $\begin{array}{l}\text { Altitudinal } \\
\text { Belt }\end{array}$ & $\begin{array}{l}\text { Water } \\
\text { Taking }\end{array}$ & $\begin{array}{l}\text { Water } \\
\text { Supply }\end{array}$ & $\begin{array}{l}\text { Returned } \\
\text { Water }\end{array}$ & $\begin{array}{l}\text { Non-returned } \\
\text { Waters }\end{array}$ & $\begin{array}{l}\text { Polluted } \\
\text { Waters } \\
\end{array}$ & $\begin{array}{l}\text { Dilution Volume } \\
\text { of waste waters }\end{array}$ \\
\hline \multirow{3}{*}{1} & \multirow{3}{*}{ Urban Population } & $<500$ & 206 & 182 & - & 65 & 117 & 1920 \\
\hline & & $500-1000$ & 4 & 3 & - & 1 & 2 & 30 \\
\hline & & $>1000$ & 3 & 2 & - & 1 & 1 & 20 \\
\hline \multirow{3}{*}{2} & \multirow{3}{*}{ Industry } & $<500$ & 232 & 371 & 170 & 61 & 140 & 2660 \\
\hline & & $500-1000$ & 7 & 12 & 6 & 2 & 4 & 80 \\
\hline & & $>1000$ & 0 & 0 & 0 & 0 & 0 & 0 \\
\hline \multirow{3}{*}{2.1} & \multirow{3}{*}{ Hit-energetic } & $<500$ & 97 & 110 & 25 & 11 & 74 & 370 \\
\hline & & $500-1000$ & - & - & - & - & - & - \\
\hline & & $>1000$ & - & - & - & - & - & - \\
\hline \multirow{3}{*}{3} & \multirow{3}{*}{ Rural Economy } & $<500$ & 257 & 173 & - & 144 & 29 & 390 \\
\hline & & $500-1000$ & 33 & 24 & - & 21 & 3 & 65 \\
\hline & & $>1000$ & 10 & 8 & - & 7 & 1 & 25 \\
\hline \multirow{3}{*}{3.1} & \multirow{3}{*}{ Rural Population } & $<500$ & 93 & 75 & - & 67 & 8 & 200 \\
\hline & & $500-1000$ & 16 & 13 & - & 12 & 1 & 25 \\
\hline & & $>1000$ & 7 & 6 & - & 5 & 1 & 25 \\
\hline \multirow{2}{*}{3.2} & \multirow{2}{*}{ Livestock Farming } & $<500$ & 43 & 33 & - & 29 & 4 & 143 \\
\hline & & $500-1000$ & 8 & 6 & - & 5 & 1 & 37 \\
\hline
\end{tabular}




\begin{tabular}{lllllllll}
\hline$\#$ & $\begin{array}{l}\text { Main Water } \\
\text { Consumers }\end{array}$ & $\begin{array}{l}\text { Altitudinal } \\
\text { Belt }\end{array}$ & $\begin{array}{l}\text { Water } \\
\text { Taking }\end{array}$ & $\begin{array}{l}\text { Water } \\
\text { Supply }\end{array}$ & $\begin{array}{l}\text { Returned } \\
\text { Water }\end{array}$ & $\begin{array}{l}\text { Non-returned } \\
\text { Waters }\end{array}$ & $\begin{array}{l}\text { Polluted } \\
\text { Waters }\end{array}$ & $\begin{array}{l}\text { Dilution Volume } \\
\text { of waste waters }\end{array}$ \\
\hline \multirow{4}{*}{3.3} & $>1000$ & 3 & 2 & - & 2 & 0 & 0 \\
& & $<500$ & 121 & 65 & - & 48 & 17 & 47 \\
& Irrigated Agriculture & $500-1000$ & 9 & 5 & - & 4 & 1 & 3 \\
& & $>1000$ & 0 & 0 & - & 0 & 0 & 0 \\
& & $<500$ & 695 & 726 & 170 & 270 & 286 & 4970 \\
& Total & $500-1000$ & 44 & 39 & 6 & 24 & 9 & 175 \\
& $>1000$ & 13 & 10 & 0 & 8 & 2 & 45 \\
\hline
\end{tabular}

\section{The Branch Specifics of Height Regularities of the Water Economy Balance}

\subsection{Drinking-Household Water Supply of Population}

In the reporting period the general drinkable, industrial and public water consumption in the inter-mountain lowlands of Georgia was approximately 580 million $\mathrm{m}^{3} / y e a r$ (as an average 610 l/twenty-four hours per city inhabitant) (table 1);

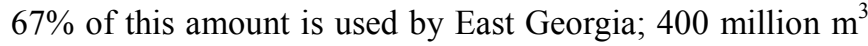
water used by sewerage system flow into rivers and reservoirs; only the least portion of these waters is preliminary filtered, which, in its turn, requires high degree of dilution with pure river water. In inter-mountain lowlands of Georgia the decontamination of the waste water used by this branch of industry requires 7000 million $\mathrm{m}^{3}$ pure river water per year, $80 \%$ of which belongs to East Georgia and makes nearly the half of its water resources.

The water supply and waste water system in the towns of Georgian mountainous regions is less developed than in lowlands. The degree of water consumption norms is also less compared to that of the lowlands. Improvement and development of public services in the highland towns involves widening and perfection of the water supply and waste water systems, which, in its turn will increase the volume of the waste waters and consequently deteriorate the qualitative conditions of natural water objects. In this case, we suppose it will be appropriate to use the public and industrial waste water after appropriate treatment for irrigation of summer pastures and technical agricultural-industrial and animal nutrition cultures.

In the reporting period approximately the half of the Georgian population lived in villages, $85 \%$ of which was the inhabitants of the lowlands. In villages the mean specific value of the water consumption according to the climatic properties of the region is 160 million $\mathrm{m}^{3}$ per year. There are quite no sewerage systems in villages. It causes heavy water consumption and the waste waters not filtered, as a rule, totally pollute 520 million $\mathrm{m}^{3}$ pure river water.

\subsection{Industry Water Supply}

The high hypsometric location, harsh climate conditions and inaccessibility of the mountainous regions cause limitations in the industry development. The specific rate of the industry production for the reporting period in the mountainous regions, which cover $54 \%$ of the territory of the country, is $1.5-2 \%$. Here the gross domestic product (GDP) is
5-10 times less than in the lowlands. In West Georgia in the up-to-500 $\mathrm{m}$ height zone and in East Georgia in the up-to-700-800 $\mathrm{m}$ height zone the GDP was $87 \%$, the main portion of the country's industry. During this period the demand on industrial water supply in the inter-mountain lowlands was 2100 million $\mathrm{m}^{3}$ water that is $52 \%$ of the whole water supply of Georgia. The approximate value of the appreciable loss is 350 million $\mathrm{m}^{3}$. It is natural that comparing this value to the existent resource potential does not make the image catastrophic. However, it is important to take into account that averaged values do not show a perfect image of the situation, namely, in some regions due to the industrial development the deficit in water resources for industrial water supply was observed. The reason of this is not only unequal distribution of the water resources on the territory but also the high rate of pollution of water objects with industrial waste waters, the dilution of which in the lowland regions requires approximately $1 / 3$ of the water resource of Georgia and nearly the full resource of East Georgia. In West Georgia there are certain basins with heavy water industrial duties as well, for example, in the basin of the river Kvirila the industrial waste waters pollute $60 \%$ of the basin resources. These data show that in the reporting period the ecological conditions of the water sphere of Georgia already required taking drastic remedies.

The insufficient degree of the industrial development in the mountainous regions refers to the necessity to study the industrial potential of the territory, primarily the natural resources of industrial significance and reveal labor resources. On the other hand, intensification of industry in the highlands is followed by ecological changes, which, in the hydrological aspect, influence on the quantitative and qualitative variations in the state of the water resources of the mountain regions. According to our calculations due to the abundance of water resources in the mountain areas the level of the industrial development in the reporting period made it possible to use the direct system of the water supply and waste the used water without preliminary filtering. However, the further industrial development and the probable water deficit in the lowlands require taking measures for the protection of water resources of the mountainous territories during the process of their use.

During mining of minerals and building numerous industrial complexes in the mountainous areas special attention must be paid to the protection of the underground waters in order to prevent their exhaustion and pollution. While using the underground waters the intense decrease of their levels and formation of wide depressive funnels deteriorate the conditions for their protection and help the 
technogenic contaminating materials move from the earth surface to aquifer horizons. In such cases the underground resources may appear inappropriate for further use, especially for drinkable water supplying. Vast underground water discharges may influence on the water flow of the whole river basin. Namely, a dramatic decrease in the underground water level and formation of vast depressive funnels deteriorate the protection degree of the underground waters and cause movement of contaminating materials from the earth surface to the aquifer horizons, also mixing of natural mineral waters from the neighboring aquifer horizons with them. Vast underground water discharges also influence on the water balance and regime of the whole river basins due to the reduced total evaporation as a result of decrease in the underground water levels. The same factors may reduce the discharge of underground waters and consequently, decrease the amount of the whole river flow.

\subsection{Irrigated Agriculture}

The most important remedies for the land farming of the mountainous areas are autumn and anti-erosion ploughs, snow retention, protection of the agricultural land from water and wind erosions by means of protective forest plants, etc. All these measures will influence on the hydrologic cycles, water resources and consequently, on the water balance of the mountain regions. Therefore, they are indirect parameters of the water industry balance. In land farming the direct parameter of the consumption component of the water industry balance mainly depends on irrigation.

In the highlands due to the lack of land resources the irrigation land farming is poorly developed. The irrigation lands are met mainly on the terraces of the river gorges, jut cones, mountain slopes and inter-mountain gorges. Usage of the gorge floodplains has become difficult due to high intensity of bogging and accumulation of solid debris during flood periods.

Due to the high level of underground waters on the gorge terraces the water loss in the irrigation net is less significant compared to filtration, and the structures of mountain slopes and jut cones of inter-mountain gorges cause high values of water loss during filtration.

More than $90 \%$ of irrigation areas of Georgia is located on lowland territories with insufficient humidity, high solar radiation and high ${ }^{\text {evaporation }}$ rate. $85 \%$ of these areas belongs to East Georgia, while the rest $15 \%$ is met in West Georgia.

In the reporting period for the irrigation of inter-mountain lowlands of Georgia approximately 2160 million $\mathrm{m}^{3}$ water was used, $90 \%$ of which belonged to East Georgia. It was planned to increase the irrigation areas by two times. Moreover, the average irrigation norm will also increase as cultivation of hygrophilous cultures in the added areas was decided. Consequently, it was supposed to increase the irrigation water volume by 2.5 times. However, the increase of the technical level of the irrigation system will make it possible to discharge the water objects for irrigation purposes only by 1.5 times. In this viewpoint it was supposed to reconstruct the physically and morally aged irrigation net with low efficiency on 230 ha area, $90 \%$ of which is located in the inter-mountain lowlands of Georgia.

Discharge of water objects for irrigation purposes significantly depends on the annual distribution of the flow, which in its turn is influenced by the height location of the irrigation area. The optimal yearly regimes of the mountain rivers for irrigation purposes are determined by snow-glacier supply as the river flood periods coincide with the maximum demand on water by the phytocenosis.

Table 3. The Height Regularities of the Water Economy Balance of West Georgia.

\begin{tabular}{|c|c|c|c|c|c|c|c|c|}
\hline \# & $\begin{array}{l}\text { Main Water } \\
\text { Consumers } \\
\end{array}$ & $\begin{array}{l}\text { Altitudinal } \\
\text { Belt }\end{array}$ & $\begin{array}{l}\text { Water } \\
\text { Taking } \\
\end{array}$ & $\begin{array}{l}\text { Water } \\
\text { Supply }\end{array}$ & $\begin{array}{l}\text { Returned } \\
\text { Water } \\
\end{array}$ & $\begin{array}{l}\text { Non-returned } \\
\text { Waters } \\
\end{array}$ & $\begin{array}{l}\text { Polluted } \\
\text { Waters } \\
\end{array}$ & $\begin{array}{l}\text { Dilution Volume } \\
\text { of waste waters }\end{array}$ \\
\hline \multirow{3}{*}{1} & \multirow{3}{*}{ Urban Population } & $<500$ & 417 & 358 & - & 96 & 262 & 4280 \\
\hline & & $500-1000$ & 36 & 32 & - & 9 & 23 & 380 \\
\hline & & $>1000$ & 9 & 8 & - & 3 & 5 & 80 \\
\hline \multirow{3}{*}{2} & \multirow{3}{*}{ Industry } & $<500$ & 1050 & 1411 & 501 & 233 & 677 & 6730 \\
\hline & & $500-1000$ & 217 & 301 & 112 & 49 & 139 & 1570 \\
\hline & & $>1000$ & 22 & 29 & 11 & 5 & 14 & 150 \\
\hline \multirow{3}{*}{2.1} & \multirow{3}{*}{ Hit-energetic } & $<500$ & 908 & 948 & 168 & 99 & 681 & 3400 \\
\hline & & $500-1000$ & - & - & - & - & - & - \\
\hline & & $>1000$ & - & - & - & - & - & - \\
\hline \multirow{4}{*}{3} & \multirow{3}{*}{ Rural Economy } & $<500$ & 1265 & 668 & - & 504 & 14 & 660 \\
\hline & & $500-1000$ & 898 & 489 & - & 374 & 115 & 535 \\
\hline & & $>1000$ & 194 & 115 & - & 92 & 23 & 205 \\
\hline & \multirow{3}{*}{ Rural Population } & $<500$ & 41 & 29 & - & 23 & 6 & 150 \\
\hline \multirow[t]{3}{*}{3.1} & & $500-1000$ & 57 & 44 & - & 38 & 6 & 145 \\
\hline & & $>1000$ & 31 & 24 & - & 21 & 3 & 75 \\
\hline & \multirow{3}{*}{ Livestock Farming } & $<500$ & 9 & 7 & - & 6 & 1 & 37 \\
\hline \multirow[t]{2}{*}{3.2} & & $500-1000$ & 26 & 20 & - & 18 & 2 & 73 \\
\hline & & $>1000$ & 23 & 18 & - & 16 & 2 & 70 \\
\hline \multirow{6}{*}{3.3} & \multirow{3}{*}{ Irrigated Agriculture } & $<500$ & 1215 & 632 & - & 475 & 157 & 473 \\
\hline & & $500-1000$ & 815 & 425 & - & 318 & 107 & 317 \\
\hline & & $>1000$ & 140 & 73 & - & 55 & 18 & 60 \\
\hline & \multirow{3}{*}{ Total } & $<500$ & 2732 & 2437 & 501 & 833 & 1103 & 11670 \\
\hline & & $500-1000$ & 1151 & 822 & 112 & 432 & 277 & 2485 \\
\hline & & $>1000$ & 225 & 152 & 11 & 100 & 42 & 435 \\
\hline
\end{tabular}




\subsection{Reservoirs and Water-Power Resources}

25 out of 43 reservoirs on the territory of Georgia with their 3,144 million $\mathrm{m}^{3}$ total volume belong to the inter-mountain lowlands. Their total volume is 1140 million $\mathrm{m}^{3}$. Every year 630 million $\mathrm{m}^{3}$ water is regulated, i.e. the natural sustainable water resources are increased by $4 \%$ by them. In Georgia the total non-industrial loss caused as a result of evaporation from the reservoir surfaces is 166 million $\mathrm{m}^{3}$ per year, 80 million $\mathrm{m}^{3}$ out of which belong to the inter-mountain lowlands.

The mountain regions are rich in potential hydro-energy resources. Their advantage in the energy viewpoint is saving of land resources for building water reservoirs. Moreover, the specific features of the highland climate and the lack of the mirror ${ }^{\text {area }}$ of reservoirs cause less evaporation from the mountain reservoir water surfaces compared to that of the same area reservoirs in the lowlands. Together with energy and irrigation functions their regulatory effects are significant for the protection of the territory from floods and mudflows, also for the water supply for the population and local industry. Moreover, it must be emphasized that mountain regions are generally characterized with active erosion-denudation processes, the intensity of which especially increases after constructing reservoirs. These processes are accompanied by violent disorders in the natural balance of the solid debris. The impact is activation of current accumulative processes in the reservoir pits. As a result the solid debris gradually fills the reservoir pit that, in its turn, makes it difficult to generate electricity. Therefore, at the reservoir design stage it is very important to accurately define the probable volume of the accumulated solid debris and the intensity of the accumulation processes in it during its exploitation, also the ecological appropriateness of development of vast energy in river basins, especially at the upper rivers in mountains.

The inequality and inappropriateness of the territorial distribution of the river flows to the population placement, industrial and agricultural loading often requires objective necessity of redistribution of water resources. In such cases during the decision making it is important to take into consideration that such kind of activities are accompanied with serious ecological results, which require systematic scientific studies and analyses.

\section{Conclusion}

The water industry estimations made it obvious that for the reporting period 6 the water amount necessary for dilution of the public, industrial and manufacture waste waters on the inter-mountain lowland of East Georgia first exceeded the local water resources of the territory and the water amount necessary for dilution of the public, industrial and manufacture waste waters in the up-to-1000-m height zone was equal to the whole resource potential of the river flow of East Georgia.

There is a different situation in West Georgia where the industrial production and agricultural irrigation lands, also the significant portion of the population are located in the $0-500 \mathrm{~m}$ height zone. In this zone the appreciable loss of the water for the necessities of the population, agriculture and industry is less than $1 \%$ of the whole river water flow and $24 \%$ of the sustainable water flow. Dilution of the waste waters requires $12 \%$ of the water resources of West Georgia. Consequently, during the reporting period on the inter-mountain lowlands of West Georgia the burning issue of the water industry optimization was not raised unlike East Georgia, though even here certain basins with heavy water industry duties were observed. It means that in less degree but in some extent even for West Georgia it was important to take more effective measure for water industry management.

It is also significant to take into consideration that mountain regions are characterized with diversity of the physical-geographical conditions and locality of the natural complexes, due to which the preservation of easily sensitive mountain ecosystems at the background of the current vast anthropological influences is quite difficult. Therefore, any water industry reorganizations in mountain regions must be carried out according only to detailed and diversified scientific researches, which, in their turn are based on complex geographical and hydrological analysis of the influence of the supposed activities on the environment.

\section{References}

[1] M. Lvovich. Water and Life. M., 1986, 254 p. (Rus.).

[2] Water balance of the Caucasus and its geographical features (consistency with natural laws). Tbilisi, 1991, 142p. (Rus.).

[3] F. Molle, D. Vallée. Managing competition for water and the pressure on ecosystems. WWAP (World Water Assessment Programme). United Nations World Water Development Report 3: Water in a Changing World. Paris/London, UNESCO Publishing/Earthscan, 2009, pp. 150-159.

[4] GWP-TAC (Global Water Partnership - Technical Advisory Committee). Integrated Water Resources Management. TAC Background Papers 4. Stockholm, GWPTAC, 2000. http://www.gwpforum.org/gwp/library/TACNO4.pdf.

[5] J. Alcamo, P.Döll, Th. Henrichs, F.Kaspar, B.Lehner, Th.Rösch, S. Siebert. Global estimates of water withdrawals and availability under current and future 'business-as-usual' conditions. Hydological Sciences Journal, 2003, volume 48, No. 3, pp. 339-348.

[6] N. Kezevadze. For the Issue of Integral Assessment and Modeling of Anthropological Loading of Water Resources. Proceedings of Vakhushti Bagrationi Institute of Geography. A new set No. 1(80), Tb., 2006, pp. 397-403. (Geo).

[7] Guidelines on Strategic Planning and Management of Water Resources. ST/ESCAP/2346. New York: United Nations, 2004, $94 \mathrm{p}$.

[8] Pres, A. 2008. Capacity building: a possible approach to improved water resources management. Water Resources Development, Vol. 24, No. 1, pp. 123-134. 
[9] I. Bitz. Trend analyses, forecasting and long-term planning of water consumption in river basin. Scientific basis for rational utilization, conservation and management of water resources. Part I, M., 1983, pp. 78-85 (Rus.)
[10] UN-Water Status Report on the Application of Integrated Approaches to Water Resources Management. UNEP, 2012. http://www.unwater.org/fileadmin/user_upload/unwater_new/ docs/UNW_status_report_Rio2012.pdf. 